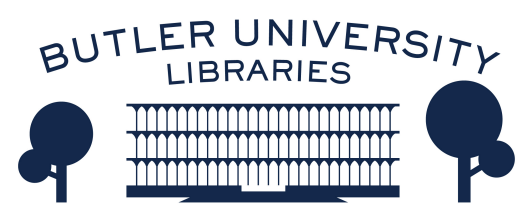

Journal of Hindu-Christian Studies

Volume 14

Article 17

January 2001

\title{
Book Review: "The South Asian Religious Diaspora in Britain, Canada, and the United States"
}

Anantanand Rambachan

Follow this and additional works at: https://digitalcommons.butler.edu/jhcs

Part of the Religion Commons

\section{Recommended Citation}

Rambachan, Anantanand (2001) "Book Review: "The South Asian Religious Diaspora in Britain, Canada, and the United States"," Journal of Hindu-Christian Studies: Vol. 14, Article 17.

Available at: https://doi.org/10.7825/2164-6279.1260

The Journal of Hindu-Christian Studies is a publication of the Society for Hindu-Christian Studies. The digital version is made available by Digital Commons @ Butler University. For questions about the Journal or the Society, please contact cbauman@butler.edu. For more information about Digital Commons @ Butler University, please contact digitalscholarship@butler.edu. 
She argues that the participants in these disputes took on new associational forms, in effect forming new types of public or political societies. Furthermore, the courts themselves, in defining caste membership supported the creation of new publics. Her distinction between acting in public and forming a public is useful in distinguishing what is new and what has pre-colonial precedents. Susan Billington Harper, in The Significance of Episcopal Extension for Church-Sate Relations in British India, discusses the consecration of Tamil missionary Vadanayan Samuel Azariah as Anglican Bishop for the newly created Dornakal Diocese. She argues convincingly that this consecration of the first indigenous Indian Anglican Bishop was achieved against great odds and through the manipulation of confusing legal and ecclesiastical procedures by two liberal bishops, Henry Whitehead and Reginald Coppleston. In The Drama of Conversions in the Courts of South India: Challenges to Aggressive Missionary Enterprise and Changing Judicial Attitudes in the Nineteenth Century, John J. Paul charts the changing attitudes of the courts to conversion to Christianity in the Madras territory. Important in these changes were the move to greater dependence on Indian law rather than English law, the religious beliefs and affiliations of judges and changing views on the age of a minor. In Routinized Charisma: The Case of Aurobindo and Auroville, Robert Minor uses Weber's theory on the routinization of charisma to argue that the Auroville's past and still current problems are a function of the fact that The Mother (Mirra Richard) did not see the need to pass her charisma on to anyone, and this in spite of the fact that Aurobindo had placed the leadership of the movement in her hands. In the process Minor provides us with a detailed and insightful account of the involvement of the courts and the Indian government in the fortunes of Auroville. Pauline Kolenda, in Memories of Brahman Agraharam in Travancore, traces the fortunes of the descendents of grantee Brahmin families living in Dharmarajapuram, a Brahmin street in Kanyakumari village. The author provides us with an insightful analysis of the "milestones" in the development of antiBrahmanism in Travancore. Particularly useful is the juxtaposition of the traditional place and roles of Brahmins in Dharmarajapuram with the current situation given largely through the voices of Brahmins themselves. In Cult Saints, Heroes, and Warrior Kings: South Asian Islam in the Making, Susan Bayly argues for the re-identification of South India as a place for the development of a regional but highly complex Islamic culture. Islam succeeded as a force in South India because it was interactive and accommodating. Bayly presents a compelling look at the way in which Islamic experiences, heroes and themes were mapped onto an existing sacred landscape.

Typographical errors notwithstanding, this is an excellent study of the formation of religious publics, their interaction with each other and with other publics. It deserves to be read by anyone interested in the religious history of India.

Ronald Neufeldt University of Calgary

\section{The South Asian Religious Diaspora in Britain, Canada, and the United States. Harold Coward, John R. Hinnels and Raymond Brady Williams, Eds. Albany: State University of New York Press, 2000, 301pp.}

ONE OF THE MOST significant and consequential developments in the religious history of the world during the latter half of the twentieth century is the transformation 
of the religious landscape of the United States, Canada and Britain through the growing presence of practitioners of the religions of South Asia. The Chinese exclusion act of 1882 , which was extended to include Filipinos, Koreans, Japanese and Indians, virtually closed the doors of the United States to people of Asian origin. In 1965, a new immigration law, initiated by John F. Kennedy, abolished quotas based on national origins and opened the country to immigrants from Asia. Changes made in the Canadian immigration law in 1986 resulted also in a sharp increase in the numbers of immigrants from South Asia. While Britain has had a longer history of immigration from South Asia, these numbers also grew during the 1960's and 70's through the migration of Asians from the East African nations of Kenya, Zanzibar, Tanzania and Uganda. Today, there are South Asian communities and places of worship in almost every major city in the United States, Canada and Britain.

While scholars, especially in the fields of sociology and anthropology, have studied many aspects of the lives of these communities, not much attention has been directed to religious belief and practice. Perhaps there was a perception that assimilation and westernization would erode tradition and minimize the continuity and significance of religion. The religious traditions of South Asia, in the United States, Canada and Britain, as this work so richly illustrates, have not faded into irrelevance, but continue to flourish and grow in their new settings. This work testifies to the fact that these traditions are now firmly planted in the western world and have taken on a truly global character. It will ensure that the study of South Asian religions be not limited, as still largely obtains, to their origins and historical development in Asia.

Six religious movements (Hinduism, Islam, South Asian Christians, New Religious Movements, Sikhism and Zoroastrianism), in the United States, Canada and Britain are the focus of this study. While the editors must be lauded for including Zoroastrianism, Sikhism and South Asian Christians, since these are often excluded in discussions of the religious life in the South Asian diaspora, one must question the omission of Jainism. The ancient Jain tradition has also successfully established itself in all three locations. Three of the twelve chapters of this volume are devoted to the study of Zoroastrianism, South Asian Christians and Indian New Religious Movements. Hinduism, Islam and Sikhism are treated separately for each country.

The extension of the discussion to cover communities in the United States, Canada and Britain amplifies the richness of the discussion by drawing attention to the distinctive circumstances and experiences of Hindus, Muslims and Sikhs in each of these countries. In addition, the reader is offered a comparison of the history, adaptation, challenges and transformation of these three traditions. Unlike many edited volumes, the comparative perspective, in this work, is not incidental. This book is the outcome of discussions at the American Academy of Religion (1995) and the School of Oriental and African Studies in London (1996). Interaction among the authors and familiarity with each other's research resulted in the identification and treatment of common themes in each discussion. Significant among these are the status of women, strategies of adaptation, public policy issues and relations with the old country. We witness, with Diana Eck, for example, the continuing vitality of the Hindu tradition as it seeks to re-create sacred geography in the United States by renaming rivers and temples after those in the homeland. Some of these, like the Sri Venkateswara in Pittsburgh, have become the focus of pilgrimage for Hindus throughout North America. At the same time, we speculate, with Harold Coward, about the theological and personal implications of the changes associated with Hindu death rituals in Canada. The outdoor funeral pyre has been replaced by a hightechnology furnace and the eldest son does not physically light the fire. "When the body 
and the fire are not seen," writes Coward, "it takes an act of imagination to connect what is happening inside the closed casket and high-tech furnace with the reintegration of the person's body/soul with the divine cosmos through the bright fire of the god Agni. The ritual loses some of its immediate symbolic power to interpret death as moving from the transience of the body to the unity of all creation in the Divine." Kim Knott reminds us of the new demands made on the Hindu tradition in Britain by youths requiring English-medium instructional materials, leadership opportunities, ethical engagement and more public responsibilities for women.

The journey of South Asian religious traditions in the United States, Canada and Britain, while historically young, is of tremendous significance, not only for these countries, but also for the development of these religions in the old country. In an era of globalization, change and transformation in the diaspora will eventually affect the meaning and practice in their places of origin. The direction of influence will not only flow from the old to the new. In this work, a group of distinguished scholars have commenced the work of noting the historical landmarks in this journey and of identifying and commenting on the issues which are and which will grow in significance as the journey continues. With this work, we will hopefully see more attention given to the study of South Asian traditions in their western homes along with the more traditional courses devoted to textual and doctrinal developments in Asia.

Anantanand Rambachan Saint Olaf College

\section{Protestant Origins in India: Tamil Evangelical Christians, 1706-} 1835. D. Dennis Hudson. Grand Rapids: William B. Eerdmans Publishing Company; Richmond (UK): Curzon Press, Ltd., 2000, xi + 220 pp.

THIS FINE VOLUME complements Daniel Jeyaraj's Inkulturation in Tranquebar (Erlangen: Verlag der Ev.-Luth. Mission, 1996; reviewed in this Bulletin in 1999), and Brijraj Singh's The First Protestant Missionary to India: Bartholomaeus Ziegenbalg 1683-1719 (New Delhi: Oxford University Press, 1999). Like Yeyaraj and Singh, Hudson begins his account with Ziegenbalg and the early $18^{\text {th }}$ century Protestant mission in Travancore, which was a Dutch East India trading post in the Tanjore district of Tamil Nadu. Hudson's work particularly complements that of Jeyaraj, while developing the theme with a closer focus on fresh biographical materials. On the whole, Hudson is less interested in the European missionaries and more interested in the indigenous Christian community, the nature of the emerging Protestant - Evangelical - Tamil Christian community.
Hudson is acutely and expertly aware throughout of the ways in which Tamil culture, language and religion shaped the particular kind of Christian identity. As he states in the preface, certain traditional questions came to life for the first Protestant converts in Tamil Nadu: "To what had they converted when German Pietist Lutherans baptized them in the Danish colony of Tranquebar? Was it a style of living that prescribed certain foods and certain modes of social behaviour, as was true for the Muslims of India, or was it something else? What did it mean to follow the command, 'Love you neighbor as yourself', and who was to decide?" (p. x) Since Hudson is wellversed in Tamil studies, he brings a sophisticated and multi-faceted sensitivity to the material, highlighting the different representations of religion and culture put forward by Christian and Hindu, Indian and foreigner, alike. 